\title{
A light- and electron microscopic study of primordial germ cells in the zebra fish (Danio rerio)
}

\author{
Nazan Deniz Koç', Rikap Yüce² \\ 1 Sakarya University, Faculty of Science and Letters, Department of Biology, Sakarya-Turkey \\ 2 Marmara University, Faculty of Science and Letters, Department of Biology, Istanbul-Turkey
}

\begin{abstract}
In sexually reproducing organisms, primordial germ cells (PGCs) give rise to the cells of the germ line, the gametes. In many animals, PGCs are set apart from somatic cells early during embryogenesis. This study explores the origin of primordial germ cells (PGCs) of the zebra fish and examines their morphology during early development $\left(1^{\text {st }}\right.$ day- $15^{\text {th }}$ day). PGCs were selectively stained by the alkaline phosphatase histochemical reaction and viewed by light and electron microscopy from the time they are first detectable in the yolk sac endoderm. PGCs occurred in the subendodermal space on the syncytial periblast; differing from the surrounding endodermal cells. Later the PGCs moved to between the blastoderm and yolk sac and transferred to the dorsal mesentery where they formed gonadal anlage with mesoderm cells. PGCs were easily distinguished from somatic cells by their morphology and low electron density of their nuclei. Under light microscopy,

PCGs were rounded with a distinct cytoplasmic membrane.
\end{abstract}

Key Words: Primordial germ cell, zebra fish, ultrastructure, morphology.

\section{INTRODUCTION}

In many different organisms, primordial germ cells (PGCs) are specified early in development in a position that is distinct from that of the gonad, the location where they differentiate into gametes (Nieuwkoop and Sutasurya 1979, Santos and Lehmann 2004, Raz 2004). Therefore, the cells have to reach the somatic part of the gonad in a process that, in addition to its crucial role in the propagation of the species, serves as a general model for long-range cell migration. PGC migration has been studied in diverse vertebrate and invertebrate species. These investigations highlighted the important role of somatic cells that act along the migratory route, offering a permissive environment for cell migration and directing the cells by providing attractive or repulsive cues.

Fish PGCs appear similar to those of mammals, reptiles and amphibians, in being large and having a large and spherical nucleus, and numerous lipid droplets in the cytoplasm (Fuyuta et al. 1974, Yasuda et al. 1992). There are numerous studies in the literature explaining the structural and histological features of primordial germ cells (Bendel-Stenzel et al.1998, Braat et al. 1999b, Buehr 1997, Dixon 1994, Hamaguchi 2004c, Kobayashi 2003, Mackay et al. 1989, Raz 2004). Germ cell specification in fish was studied mainly in bony fish (teleosts) where the work relied on observations using light and electron microscopy. Early germ cells were studied by electron microscopy chiefly in freshwater species such as Oryzias (Hogan 1973), Brachydanio (Baumeister 1976), Salmo (Upadhyay 1977) and Mugil (Brusle 1978). The germ cells were recognized by their large size and by the typical electron dense nuage-like structures. Their peripheral cytoplasm shows high alkaline phosphatase activity; alkaline phosphatase is used as indicator enzyme. Alkaline phosphatase (an enzyme which is found in the cell or in the cell membrane and active at pH 8.5-10 with the ability of detaching phosphate groups) activity was also observed in the peripheral cytoplasm of primordial germ cells.

It thus seemed of interest to use electron and light microscopy to define the histological characteristics of primordial germ cells in the embryo and larva of zebra fish.

\section{MATERIAL \& METHODS}

Light Microscopy

The zebra fish embryos and larvae were fixed in Bouin's solution for 8 hours. Fixed embryos and larvae were dehydrated and embedded in paraffin wax and sectioned transversely at 5-7 $\mu \mathrm{m}$ thickness and stained with Hematoxylin\&Eosin, Best Carmin, and Alkaline Phosphatase stain. Samples were evaluated by examining under light microscope.

\section{Electron Microscopy}

For transmission electron microscopy individual eggs were fixed by immersion in a solution containing $4 \%$ paraformaldehyde and $0.1 \%$ glutaraldehyde in $0.1 \mathrm{M}$ phosphate buffer at $\mathrm{pH} 7.4$ for $4 \mathrm{~h}$. The chorion was subsequently removed and the eggs were fixed further overnight at $4^{\circ} \mathrm{C}$ using $2 \%$ glutaraldehyde in $0.1 \mathrm{M}$ phosphate buffer at $\mathrm{pH}$ 7.4. After an additional fixation with $1 \% \mathrm{OsO}_{4}$ and pre-embedding staining with $1 \%$ uranyl acetate, eggs were dehydrated and embedded in Embed 812 resin. The sectioning was performed using a Leica Ultracut ultramicrotome. Thick sections were stained with tolouidine blue and visualized in an Olympus light microscope to select the area of interest. 
Thereafter, thin sections were collected and counterstained with $1 \%$ uranyl acetate and lead citrate and examined using a transmission electron microscope.

\section{RESULTS}

In this study, histology and morphology of primordial germ cells in zebra fish embryos and larvae were examined following fertilization. Primordial germ cells in zebra fish were first identified in the segmentation phase after fertilization. Since primordial germ cells differ from somatic cells in their morphology and histology, these cells can be identified easily. In the development phase of embryo and larva, some changes were observed in the morphology and histology of cells in specific stages. It was observed that migrating cells were lengthened and spindle-shaped whereas static cells were rounded-elliptical shaped. These cells had more granulated structure than the somatic cells. "nuage material", which plays an important role in the identification of primordial germ cells in later phases of development, was first identified in the larval period.

Morphology: Primordial germ cells were identified according to their structural (morphological) properties; round shapes, large sizes, large nucleus and marked nuclear membrane. They are characterized by high electron cytoplasm density and have a very irregular outline.

\section{Cytology:}

Nuclear characteristics: The nucleus is voluminous (nucleus/ cytoplasm) and eccentrically located. The outline of the nuclear envelope is irregular and the nucleoplasm contains widely dispersed chromatin. The single nucleolus situated eccentrically consists of center and a large.

Cytoplasmic characteristics: It was observed that these cells were morphologically larger and stained more densely than peripheral somatic cells. Furthermore, they were more evident in Best Carmin staining because glycogen density was greater. In the Best Carmin staining, dense red granular bodies were identified in the cytoplasm of these cells. Also, the structures with granules known as "nuage materials" were seen in the primordial germ cells studied with this staining method. In the identification of primordial germ cells during the light microscopy stage, "nuage material" played very important role due to its shape. Many ribosomes are freely dispersed throughout the cytoplasm, making it very electrondense. Most mitochondria are round-shaped.

\section{Light microscopy:}

In the first day after fertilization, primordial germ cells in larger sizes than normal were observed under the endomesoderm in the area next to the vitellus and around the blastoderm. In the first $24 \mathrm{~h}$ after fertilization, the size of primordial germ cells was approximately 10-20 $\mu \mathrm{m}$. When the cell morphology was examined in detail, it was observed that the cell structure was dense and granular. These dense granular bodies were considered as ribosomes or glycogen granules. It was observed that primordial germ cells were surrounded by somatic cells and they were positioned as groups of 2-3 cells near the vitellus in the dorsal side of blastoderm. The cells were identified according to their large sizes, large nuclei and sometimes by their structure including two nucleoli. Primordial germ cell cytoplasm was more granular than the somatic cell cytoplasm. The size of primordial germ cell nucleus was approximately 6-8 $\mu \mathrm{m}$ and it covered the majority of the cytoplasm. It was observed that elliptical-shaped cell nucleus was modified by cytoplasmic alterations during the migration (Figure $1 \mathrm{a}, \mathrm{b}$ ).

At day 5 post fertilization ( $5 \mathrm{dpf}$ ), primordial germ cells were in the upper side of body cavity (in the area of gonadal anlage) and in the inferior boundaries of the vitellus. The measurements demonstrated that the cell sizes were between 10 and $20 \mu \mathrm{m}$. Primordial germ cells were considerably larger than the surrounding cells. In the semi-thin sections of pre-5 day old larvae (prelarvae) it was found that the elliptical shape of primordial germ cells was changed into a spindle form (This situation is related to alterations in cell shapes during migration). Developing primordial germ cells moved across the body close to the vitellus sac (Figure $1 \mathrm{c}$ ).

In the 7-day old zebra fish prelarvae, primordial germ cells were seen closer to the body cavity and in the boundaries of the vitellus. The cell sizes were not changed. The cells were nearly $10-20 \mu \mathrm{m}$ and they were larger than somatic cells. The nuclei were large as in the other sections and they covered the majority of cytoplasm. Because granular structures called as nuage materials are specific to primordial germ cells, they could be seen obviously in the sections. These granules were observed as distributed in the cytoplasm around the nucleus (Figure $1 \mathrm{~d}$ ).

We preferred this staining method because of high alkaline phosphatase activity in primordial germ cells. In 13-day and 15-day old larva, the cells with high alkaline phosphatase activity were stained as dark brown or black via Best Carmin staining. In this period, the cells were in the dorsal side of the vitellus sac and between the body cavity and somites, and were approximately $12 \mu \mathrm{m}$ in size. The nuclei of primordial germ cells were large and 6-10 $\mu \mathrm{m}$ in size. It was determined that in these cells alkaline phosphatase activity in the nucleus and surroundings was quite high. The cells were monitored in the same sections stained by this method and the comparator staining method and it was confirmed that these cells were definitely primordial germ cells. The differences in size between primordial germ cells and somatic cells could be monitored easily in semi-thin sections of $1 \mu \mathrm{m}$ stained by tolouidine blue (Figure 1e,f and Figure 2a).

Electron microscopy: According to the results of examination by electron microscope, primordial germ cells from embryos and larvae of zebra fish were elliptical or flat due to the direction of section. The nuclei of primordial germ cells covered the majority of the cytoplasm and their boundaries were irregular. Chromatin was distributed homogenously in the nucleus cytoplasm. The nucleolus was clear. The cytoplasm of primordial germ cells (germinal cytoplasm) was stained clearly. The cytoplasm was dense and granular. Although there were ribosomes, glycogen granules and many mitochondria in the cytoplasm, endoplasmic reticulum and the Golgi complex were insufficiently developed. In the comparison of primordial germ cells and 
surrounding somatic cells, it was determined that there were differences in terms of size and structure. Primordial germ cells had more mitochondria compared to somatic cells. Also, electron-dense structures were striking in the cytoplasm. These structures were not surrounded by a membrane. The structure of cytoplasm was thin-fibrillary and reticular. Lipid droplets were seen sporadically in the germinal cytoplasm. It was noticed that nuage material was more dense around the mitochondria (Figure $2 b, c, d$ ).

\section{DISCUSSION}

Primordial germ cells in zebra fish embryos were examined as of the $10^{\text {th }}-11^{\text {th }}$ hour after fertilization $(10 \mathrm{hpf})$ by light microscope and the structure of these cells was similar to that of members of Osteichthyes such as medaka (Hamaguchi

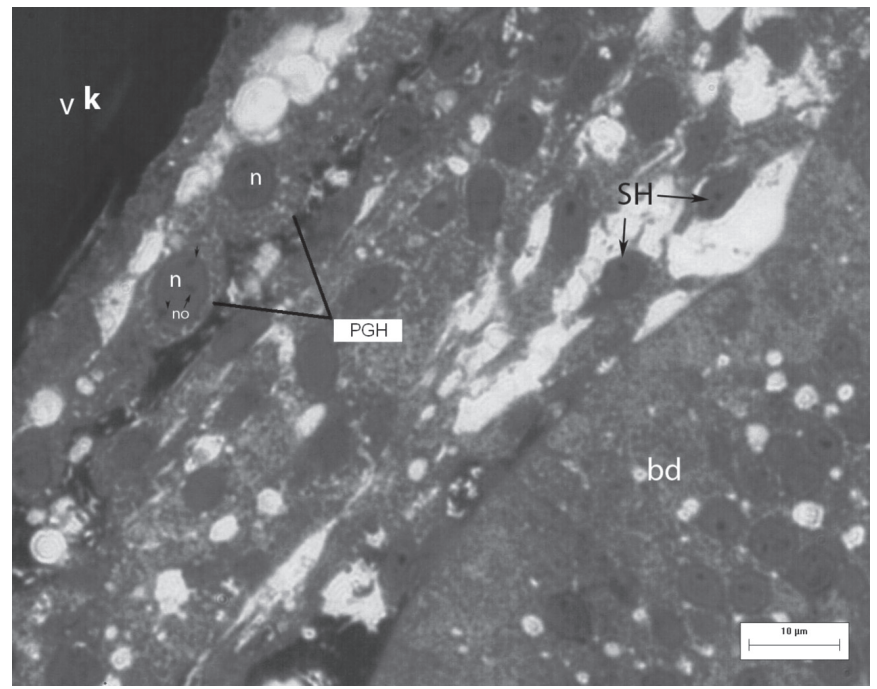

Figure 1. Primordial germ cells (PGH), blastoderm (bd), somatic cell $(\mathrm{SH})$, vitellus sac (vk), nucleus (n), nucleolus (no) observed between blastoderm layer and vitellus sac in 1-day zebra fish embryo (x100).



Figure 3. a- 5-day zebra fish prelarva, b-Primordial germ cells $(\mathrm{PGH})$, vitellus sac (vk), somatic cell (SH) observed in 5-day zebra fish prelarva. Toluidin blue a-x4, b-x100.
2004 a,b,c) and carp (van Winkoop et al. 1992, Winkoop et al. 2004). In hatched fish, primordial germ cells can be recognized histologically by their large size, low nucleus/cytoplasm ratio, clear nuclear borders, and granular nuclear chromatin (Dietrich and Krieger 2009). It was difficult to distinguish PGCs from other somatic cells before the bud stage using morphological features, especially their size and shape. In this study, primordial germ cells were detected in the later stages of the blastula phase (4hpf; late blastula phase). According to some of the literature it is not possible to detect the primordial germ cells as tissue before the segmentation phase. Primordial germ cells have different features morphologically and histologically than somatic cells. These cells are known to be more granular than somatic cells. The differences between the primordial germ cells and somatic cells were detected by PAS, Best Carmin and alkaline phosphatase staining methods.

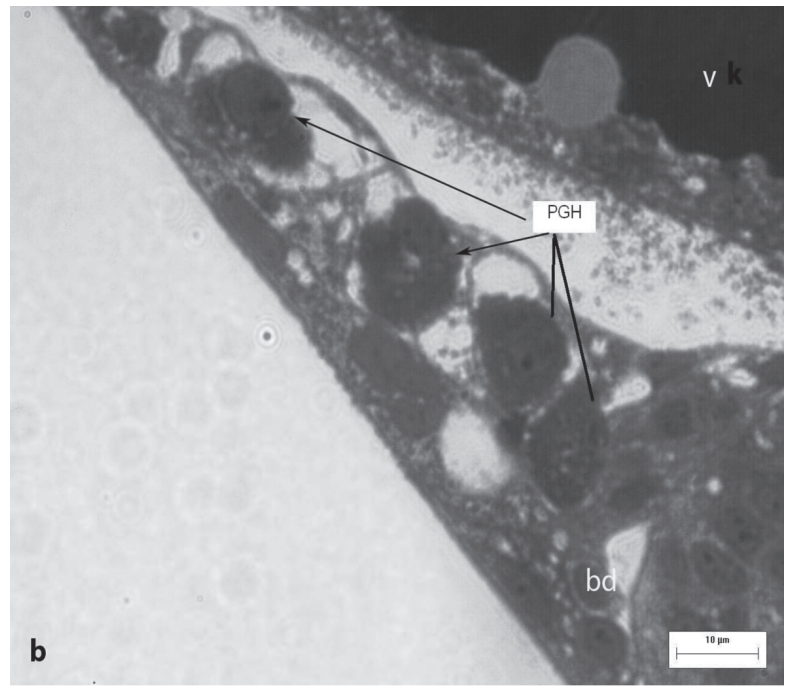

Figure 2. Primordial germ cells $(\mathrm{PGH})$, blastoderm (bd), vitellus $\mathrm{sac}(\mathrm{vk})$ detected in the terminal area of blastoderm in 1-day zebra fish embryo. Toluidin blue. a-(x40),b- (x100).



Figure 4. a- 7-day prelarva; b- Primordial germ cells (PGH), muscle layer (k), body cavity (vb) detected in 7-day prelarva. Best Carmin Staining $\times 100$. 


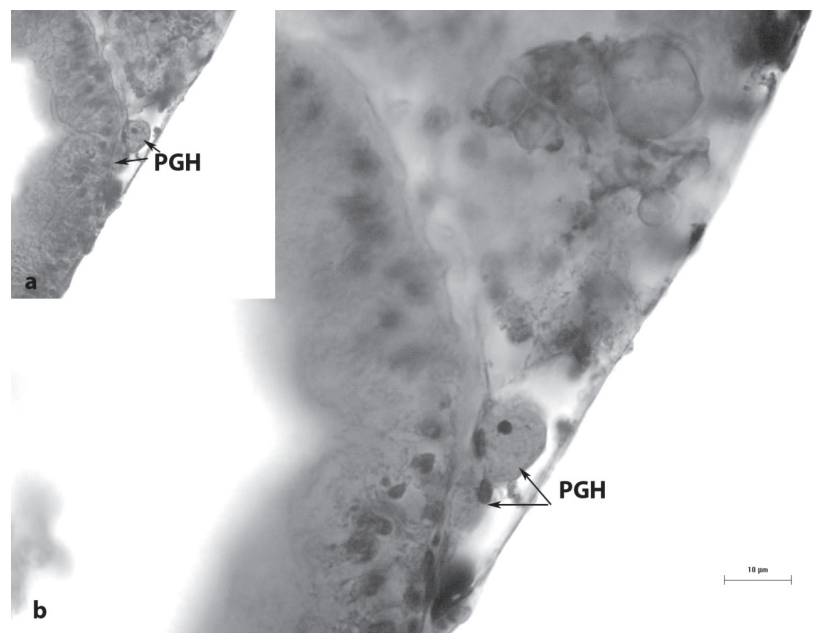

Figure 5. Primordial germ cell in 13-day larva.

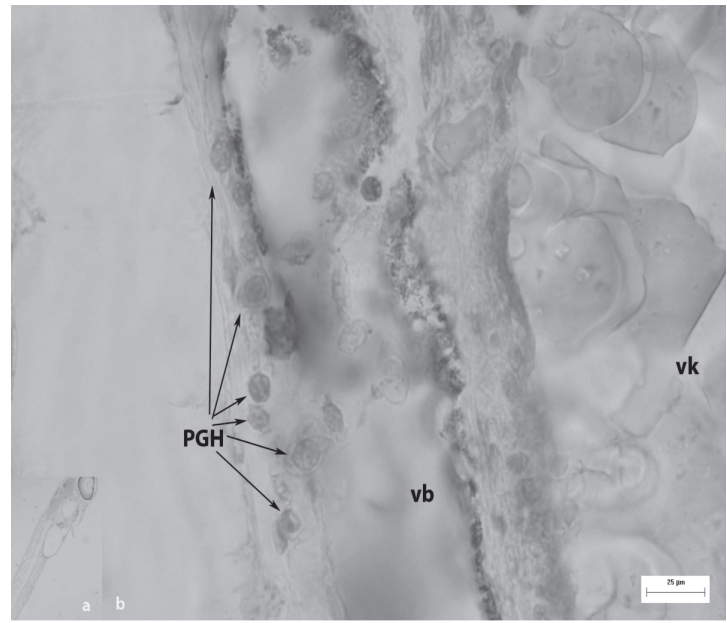

Figure 7. a-15-day zebra fish larva, b- Primordial germ cells (PGH), vitellus sac (vk), body cavity (vb) chosen in 15-day zebra fish larva. Toluidin blue. a-x4, b-x40. Best Carmin a-x4, b-x40.

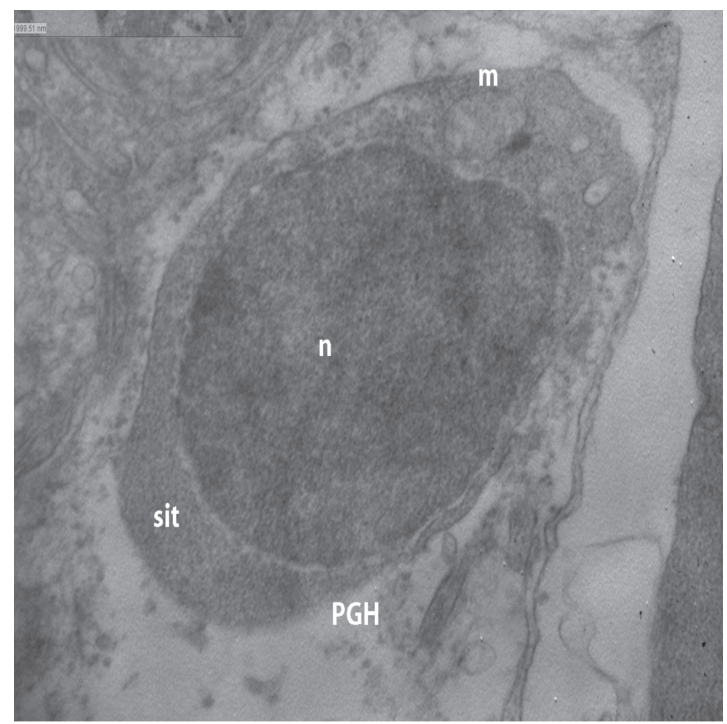

Figure 9. Primordial germ cell (PGH), nucleus (n), cytoplasm (sit), mitochondria $(\mathrm{m})$ seen in boundaries of body cavity in 15-day zebra fish embryo. X30000.

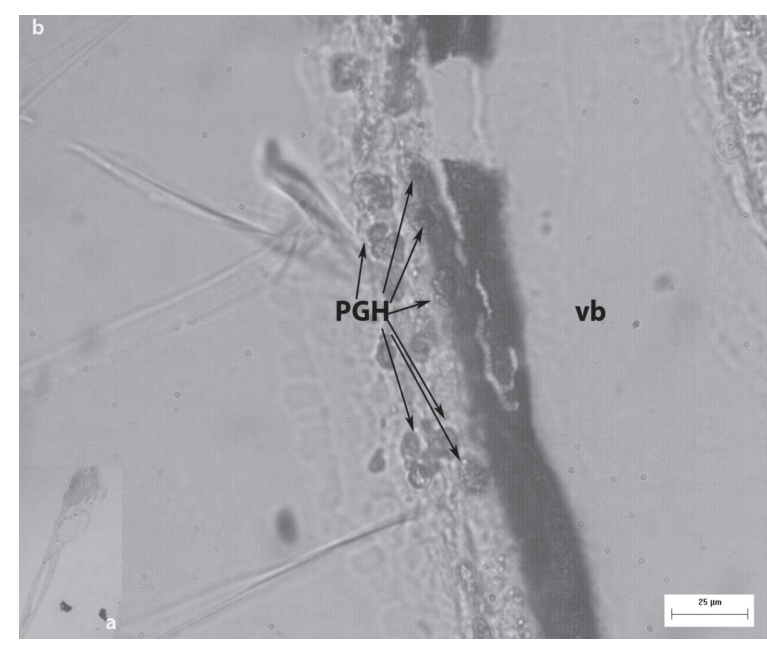

Figure 6. a-15-day zebra fish larva, b- Primordial germ cells (PGH) somatic cell $(\mathrm{SH})$, body cavity $(\mathrm{vb})$ chosen in 15-day zebra fish larva. Alkaline phosphatase stain. $\mathrm{a}-\mathrm{x} 4, \mathrm{~b}-\mathrm{x} 40$

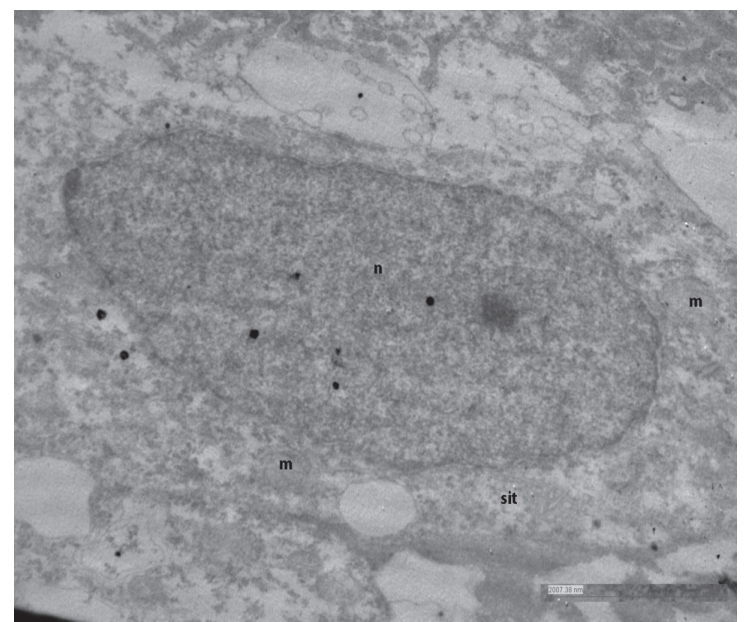

Figure 8. Thin structure of primordial germ cell $(\mathrm{PGH})$, nucleus $(\mathrm{n})$, cytoplasm (sit), mitochondria (m) in section area from blastoderm boundary in 7-day zebra fish embryo. X 15.000



Figure 10. Primordial germ cell (PGH), nucleus ( $n)$, cytoplasm (sit), mitochondria $(\mathrm{m})$ seen in boundaries of body cavity in 15day zebra fish embryo. X30000. 
Primordial germ cells in Osteichthyes were first identified in peripheral (surrounding) endoderm in 46-53 hour old Fundulus heteroclitus embryos by Richards and Thompson (1921). In this study, it was emphasized that there was a close relationship between the periblast layer and primordial germ cells. Johnston (1951) showed the presence of primordial germ cells in the exaggerated end of the periblast, bulging at the caudal end (tail area) of the blastodisc in Microptreus salmoides. It was detected that these cells moved from the caudal bulge of the yolk and in the later phases they migrated to the caudal periblast. Primordial germ cells in Gambusia holbrookii (Pala 1970) were observed in the early gastrula phase partially in the caudal portion of the blastodisc. Nedelea \& Steopoe (1970) specified that primordial germ cell numbers were limited in the mesodermal layer of embryonic theshield towards the end of vitellus growth in carp. Primordial germ cells were clearly distinguishable from somatic cells in the embryonic stage by the appearance of granules of melanin pigment in the eyes in medaka fish. The cells characteristically had a large size of the cell and nucleus (about 15 and 8/an in diameter respectively), a distinct round outline, a less stained cytoplasm, and a single, clear nucleolus (Satoh and Egami 1972). Primordial germ cells (PGC) were oval unstained cells in Epinephelus marginatus. They were relatively large (12-24 $\mathrm{mm}$ in diameter) and usually arranged in clusters of a few cells, both along the edge and the axis of the ovigerous folds. The diameter of the nucleus ranged between 9 and $15 \mathrm{~mm}$. The nucleus/cytoplasm ratio was about 0.7 (Mandich et al. 2002). The sizes of primordial germ cells cleaving from the somatic cells were examined in the early segmentation phase of Micrometus aggregatus (Eigenmann 1981). Primordial germ cells in carp were first observed in the second week of fertilization and then an increase was detected in the cell size in the $2^{\text {nd }}$ $-4^{\text {th }}$ weeks. In previous studies, it was explained that there was a close relationship between the electron-dense structures and mitochondria and the presence of marked Golgi complex was shown (Van Winkoop et al. 1992). On the other hand, in primordial germ cells of zebra fish, the same close relationship was demonstrated for mitochondria and nuage material (deeply stained areas in the polyribosome structure) but the Golgi complex was insufficiently developed. In the $3^{\text {rd }}$ month of fertilization in Mugil cephalus elliptical and large primordial germ cells with large nucleus were observed in gonads (Chang et al. 2005). In a study of Gymnogobius species, it was reported that primordial germ cells were elliptical-shaped with large nucleus and markedly surrounded by a nuclear membrane. In this study, primordial germ cells were found to be $10-20 \mu \mathrm{m}$ in the experimental species. Primordial germ cells in this species were monitored from the phase with 10 somites (Saito et al. 2004). On the other hand, in our study we detected primordial germ cells in $10^{\text {th }}-11^{\text {th }} \mathrm{hr}$ approximately and observed that cells were in a close relationship with the periblast. The primordial germ cells and their nuclei were larger than somatic cells. Primordial germ cells were approximately 10-20 $\mu \mathrm{m}$. We observed that there were deeply stained granules around the nucleus in PAS and Best Carmin staining in zebra fish. Also a few eosinophilic granules were observed in the cytoplasm near the nuclei of primordial germ cells in medaka (Oryzias latipes) (Hamaguchi 2004a, b). Because the dense structures were stained especially around the nucleus in primordial germ cells in Barbus conchonius, they were considered as similar to "nuage material", and following staining with eosin and gallocyanin, proteins and RNA could be seen easily (Gevers et al. 2004). Furthermore, it was shown that this nuage material observed around the nucleus membrane was in a close relationship with mitochondria. The nuage-mitochondria relationship was considered as an important parameter for germ cell development. The relation of nuage-mitochondria structure was examined in Piaractus mesopotamicus by Abdalla and Cruz-Landim (2004) and our results are consistent with their findings. Abdalla and Cruz-Landim reported that germ cell differentiation could not be occurring in the periods of defective mitochondria-nuage relation in the cytoplasm. Thin structure studies play an important role in understanding the structure of primordial germ cells. On the other hand, information about primordial germ cells in fish is limited in the literature. One of these studies was performed in Cyprinus carpio and gonadal development and primordial germ cell differentiation were identified in a six-week incubation period (Van Winkoop et al. 1992, Winkoop et al. 2004). It was noted that the cells differentiated rapidly following this period and due to the increase in the cell size, perinuclear dense structures became more pronounced. It was emphasized that a dense Golgi complex was detected in these cells by a thin structure study and in parallel to the size increase of cells, synthetic activity increased. In our study the Golgi complex was not detected rigorously whereas the cells were rich in ribosomes and mitochondria. vasa RNA embedded in electron-dense structures similar to the nuage material was found in O. latipes via a TEM study (Hamaguchi 2004c).

\section{REFERENCES}

ABDALLA FC, CRUZ-LANDIM C (2004) Occurrence and Ultrastructural Characterization of "Nuage" During Ooogenesis and Early Spermatogenesis of Piaractus mesopotamicus Holmberg, 1887 (Teleostei). Braz J Biol. 64(3B): 555-561.

BAUMEISTER HG (1976) Multiple Nukleolen und RNS-Synthese in der Oogenese von Brachydanio rerio (Teleostei). Zool Jb Anat Bd. 95:165-185

BRUSLE S, BRUSLE J (1978) An ultrastructural study of early germ cells in Mugil (Liza) auratus Risso, 1810 (Teleostei:Mugilidae) Ann Biol Anim Bioch Biophys. 18(5): 1141-1153.

CHANG CH, LAN SH, CHOU HY (2005) Gonadal Histology and Plasma Sex Steroid During Sex Differentiation in Grey Mullet, Mugil cephalus. Journal of Experimental Zoology 272(5):395-406.

DIETRICH D, KRIEGER, HO (2009) Histological Analysis of Endocrine Disruptive Effects in Small Laboratory Fish. John Wiley \& Sons, New Jersey. p 25.

EIGENMANN CH (1981) On the Prococious Segragation of the Sex Cells in Micrometus aggregatus Gibbons. J Morphol. 5: 481-92.

FUYUTA M, MIYAYAMA Y, FUJIMOTO T (1974) Histochemical identification of primordial germ cells in human embryos by PAS reaction. Okajimas Folia Anat Jap. 51(5): 251-262.

GEVERS P, DULOS J, BOOGAART JGM, TIMMERMANS LPM (2004) Study on Cell Lineage, Especially the Germ Cell Line, in Embryos of the Teleost Fish, Barbus conchonius. Devt Genes and Evol. 201: 275-283.

HAMAGUCHI S (2004a) The Structure of the Germinal Dense Bodies (nuage) During Differentiation of the Male Germ Line of the Teleost, Oryzias latipes. Cell Tissue Res. 248: 375-380.

HAMAGUCHI S 82004b) Sex Differentation of Germ Cells and Their Supporting Cells in Oryzias latipes. MSc Thesis, Department of Biology, College of General Education, Niigata University, Japan.

HAMAGUCHI S (2004c) Light and Electron Microscopy study on the Migration of Primordial Germ Cells in the Teleost, Oryzias latipes. Cell and Tissue Research 227:139-151.

HOGAN JC (1973) The fate and fine structure of primordial germ cells in the teleost, Oryzias latipes. J Cell Biol. 59: 146a.

JONSTON PM (1951) The Embriyonic History of the Germ Cells of the Largemouth Black Bass Micropterus salmoides (Lacepede). J Morphol. 88: 471-542. 
MANDICH A, MASSARI A, BOTTERO S, MARINO G (2002) Histological and histochemical study of female germ cell development in thedusky grouper Epinephelus marginatus (Lowe, 1834). Eur. J. Histochem. 46: 87100.

NEDELEA M, STEOPOE I (1970) Origine, Cracteres Cytogiques et Comportement Des Gonocytes Primaires Pendant l'embryogenese et Chez Les Jeunes Larves de Cyprinus carpio L. (Teleosteens). Anat Anz. 127: 338-46.

NIEWKOOP PD, SUTASURYA LA (1979) Primordial germ cells in the chordates: Embryogenesis and Phylogenesis, Cambridge University Pres, pp118-123.

PALA M (1970) The Embriyonic History of the Primordial Germ cells in Gambusia holbrookii (Grd). Boll Zool. 37,:49-62

RAZ E (2003) Primordial germ-cell development: the zebrafish perspective. Nat Rev Genet. 4:690-700.

RAZ E (2004) Guidance of primordial germ cell migration. Curr Opin Cell Bio. 16(2):169-173

RICHARDS A, THOMPSON JT (1921) The Migration of the Primary Sex-cells of Fundulus heteroclitus. Biol Bull. 40: 325-49.

SAITO T, OTANI S, FUJIMOTO T, SUZUKI T, NAKATSUJI T, ARAI K, YAMAHA E (2004). The Germline Lineage im Ukigori, Gymnogobius
Species (Teleostei: Gobiidae) During Embryonic Development. Int J Dev Biol 48: 1079-1085.

SANTOS AC , LEHMANN R (2004) Germ cell specification and migration in Drosophila and beyond, Curr Biol. 14: 578-589.

SATOH N, EGAMI, N (1972) Sex differentiation of germ cells in the teleost, Oryzias latipes, during normal embryonic development. J. Embryol. Exp. Morph. 28 (2): 385-395.

UPADHYAY SN (1977) Morphologie des gonades immatures et etude experimentate de l'induction de la gametogenese chez la truite arc-enciel juvenile (Salmo gairdneri R.). These Doct. Sci. Univ.Paris VI, p 111.

VAN WINKOOP A, BOOMS HGR, DULOS GR, TIMMERMANS LPM (1992)

Ultrastructural Changes of Primordial Germ Cells During Early Gonadal Development of the Common Carp ( Cyprinus carpio L., teleostei). Cell and Tissue Research 267:337-346.

WINKOOP V, BOOMS GHR, DULOS GJ, TIMMERMANS LPM (2004) Ultrastructure changes in primordial germ cells during early gonadal development of the common carp (Cyprinus carpio L., teleostei). Cell Tissue Res. 267(2): 337-346.

YASUDA Y, TAJIMA A, FUJIMOTO T, KUWANA TA (1992) A method to obtain avian germ line chimeras using isolated primordial germ cells. J Reprod Fert. 96:521-528. 